\title{
Effect of the classic ketogenic diet on the treatment of refractory epileptic seizures ${ }^{1}$
}

\author{
Efeito da dieta cetogênica clássica no tratamento \\ de crises epilépticas refratárias
}

\author{
Luciana Duarte MARTINS 2 \\ Vera Cristina TERRA ${ }^{2}$ \\ Carolina Ferreira NICOLETTI ${ }^{3}$ \\ Paula Garcia CHIARELLO ${ }^{3}$ \\ Julio Sérgio MARCHINI ${ }^{3}$ \\ Américo Ceiki SAKAMOTO2 \\ Carla Barbosa NONINO-BORGES ${ }^{3}$
}

A B S T R A C T

\section{Objective}

The ketogenic diet is used as a therapeutic alternative for the treatment of epilepsy in patients with refractory epilepsy. It simulates biochemical changes typical of fasting. The present study verified the nutritional impact of the ketogenic diet on children with refractory epilepsy.

\section{Methods}

Nutritional status data (dietary, biochemical and anthropometric measurements), seizure frequency, and adverse events were collected from the medical records and during outpatient clinic visits of children over a period of 36 months.

\section{Results}

Of the 29 children who initiated the ketogenic diet, $75.8 \%$ presented fewer seizures after one month of treatment. After six months, $48.3 \%$ of the patients had at least a $90.0 \%$ decrease in seizure frequency, and $50.0 \%$ of these patients presented total seizure remission. At 12 months, eight patients continued to show positive results, and seven of these children remained on the ketogenic diet for 24 months. There was an improvement of the nutritional status at 24 months, especially in terms of weight, which culminated with the recovery of proper weight-for-height. There were no significant changes in biochemical indices (total cholesterol

\footnotetext{
1 Artigo elaborado a partir da dissertação de LD MARTINS, intitulada "Efeito da dieta cetogênica clássica no tratamento de crises epilépticas refratárias". Universidade de São Paulo; 2007.

2 Universidade de São Paulo, Faculdade de Medicina de Ribeirão Preto, Hospital das Clínicas, Departamento de Neurologia, Psiquiatria, Psicologia e Médica. Ribeirão Preto, SP, Brasil.

${ }^{3}$ Universidade de São Paulo, Faculdade de Medicina de Ribeirão Preto, Hospital das Clínicas, Departamento de Clínica Médica. Av. Bandeirantes, 3 900, 14048-900, Ribeirão Preto, SP, Brasil. Correspondence to/Correspondência para: CB NONINO-BORGES. E-mail: <carla@fmrp.com.br>.
} 
566 | LD MARTINS et al.

and components, triglycerides, albumin, total protein, creatinine, glycemia, serum aspartate transaminase and serum alanine transaminase). Serum cholesterol levels increased significantly in the first month, fell in the following six months, and remained within the normal limits thereafter.

\section{Conclusion}

In conclusion, patients on the classic ketogenic diet for at least 24 months gained weight. Moreover, approximately one third of the patients achieved significant reduction in seizure frequency, and some patients achieved total remission.

Indexing terms: Epilepsy. Ketogenic diet. Nutritional status.

\section{R E S U M O}

\section{Objetivo}

A dieta cetogênica é empregada como uma terapia alternativa para o tratamento da epilepsia em pacientes com epilepsia refratária e simula as alterações bioquímicas de jejum. Neste trabalho, verificou-se o impacto nutricional da dieta cetogênica em crianças com epilepsia refratária.

\section{Métodos}

Os dados sobre o estado nutricional (bioquímica, alimentar e medidas antropométricas), a frequência de crises e os eventos adversos de crianças acompanhadas durante 36 meses foram coletados de prontuários médicos e visitas ambulatoriais.

\section{Resultados}

Vinte e nove crianças iniciaram o tratamento; após um mês, 75,8\% apresentaram redução das crises. Em seis meses, 48,3\% dos pacientes tiveram pelo menos 90,0\% de redução na frequência de crises, e, desses, 50,0\% obtiveram o controle completo das crises. Aos doze meses, oito pacientes continuaram a apresentar resultados positivos, e, desses, sete permaneceram em dieta cetogênica durante 24 meses. Observou-se melhora do estado nutricional aos 24 meses de tratamento, especialmente em termos de peso, o que indica a recuperação da condição peso para altura. Não houve mudanças significativas nos índices bioquímicos analisados (colesterol total e de componentes, triglicerídeos, albumina, proteína total, creatinina, glicemia, transaminase glutâmico oxala-cética sérica e transaminase glutâmico pirúvico sérica). Os níveis de colesterol aumentaram significativamente no primeiro mês, mas diminuíram nos seis meses seguintes e, posteriormente, se mantiveram dentro dos valo-res de referência.

\section{Conclusão}

Os pacientes em uso da dieta cetogênica clássica por pelo menos 24 meses apresentaram melhora de peso e cerca de um terço dos pacientes conseguiu uma redução significativa da frequência de crises, com alguns pacientes completamente livres delas.

Termos de indexação: Epilepsia. Dieta cetogênica. Estado nutricional.

\section{INTRODUCTION}

The Ketogenic Diet (KD), the so-called modified Atkins diet, and the low-glycemic index treatment have all emerged over the past decade as important therapeutic options for children with refractory epilepsy ${ }^{1,2}$. Whereas only a decade ago the KD was seen as a last resort, its global use now is more common ${ }^{1}$.

The KD simulates biochemical changes associated with fasting and is used especially in children with refractory epileptic seizures ${ }^{3}$. It could potentially be used in epileptic syndromes and specific conditions, providing specific benefits in conditions such as glucose transporter protein I (GLUT I) deficiency, pyruvate dehydrogenase deficiency (PDHD), myoclonic-astatic epilepsy (Doose syndrome), tuberous sclerosis complex, Rett syndrome, and severe myoclonic epilepsy in infancy (Dravet syndrome) ${ }^{4,5}$. This diet can also be used by patients that do not tolerate the adverse side effects of anticonvulsant drugs ${ }^{3}$.

Fasting ketosis is mimicked by using fats to provide $90 \%$ of the dietary energy and the 
remainder $10 \%$ coming from carbohydrates and proteins ${ }^{6,7}$, to a limit of $75 \%$ of the recommended daily energy intake ${ }^{8}$. The term 'ketogenic ratio' has been used to describe the ratio of ketoneproducing foods (for instance, dietary fat) to foods that reduce ketone production (for instance, carbohydrate and protein), and the most frequently used proportion is $4: 1^{8-10}$. To provide the general principles of nutrition and meet the energy, protein, mineral and vitamin requirements, patients on the KD should take multivitamin and mineral supplements on a daily basis to improve and maintain their physiological wellbeing ${ }^{11}$.

The progress of refractory epilepsy in children submitted to multidrug treatment usually leads to neurological deterioration ${ }^{12}$. Moreover, frequent seizures and post-seizure periods reduce the time a child remains awake, which may lead to low total energy intake. Side effects of antiepileptic drugs usually occur, and they increase with polytherapy. Among the undesirable effects are low appetite, difficulty chewing and swallowing, vomiting, malabsorption of nutrients like iron and zinc, and changes in energy balance. Therefore, repeated seizures and drug treatment may impair growth and cause nutritional problems, which are common in these children ${ }^{13-15}$.

Bertoli et al. ${ }^{16}$ reported that $40 \%$ of the children with refractory epilepsy have a low weight-for-age Z-score, and $24 \%$ have chronic undernourishment, that is, Low Weight-for-Height $(\mathrm{W} / \mathrm{H})$ and Height-for-Age (H/A) Z-scores. In this same study, the mean daily energy intake was below the requirement, and inadequate macronutrient intake was evident. This suggested that the diet was high in proteins and lipids, and in low carbohydrates and fibers.

The ketogenic diet has been used for the treatment of refractory epilepsy for many years with good clinical results ${ }^{17}$. Its effectiveness has been reported in many studies, which have demonstrated significant reduction in seizure frequency ${ }^{18,19}$. The aim of this study was to evaluate the effect of a classic KD on nutritional status and seizure frequency in children with refractory epilepsy before, during, and after a sixmonth period of dietary treatment.

\section{METHODS}

The present study consisted of a retrospective and a prospective stage. The 29 participants had drug-resistant epilepsy with more than one seizure daily and were thus placed on a KD. The KD was introduced during hospital stay, after a 24-hour fast. After hospital discharge, the subjects were followed in outpatient clinics. This study was approved by the local Research Ethics Committee under protocol number 12267/2005, and an informed consent was signed by all the participants' legal guardians.

The study demographic data included sex, age at epilepsy onset, age at KD introduction, epileptic syndrome diagnosis according to the classification of the International League Against Epilepsy (ILAE) ${ }^{20}$, Magnetic Resonance Imaging (MRI) and electroencephalogram (EEG) findings, seizure frequency before and after KD introduction, and clinical complications. The antiepileptic drug was not changed for at least six months after KD initiation, and then it was progressively reduced in seizure-free patients.

The use of vitamin and mineral supplements (Table 1) was initiated after KD introduction; evaluation of their necessity and efficacy was done by laboratory tests. The KD was immediately halted when there was no improvement within 2 months. KD interruption was abrupt, without a progressive reduction in the amount and ratio of fat intake.

Anthropometric assessment included weight, height, W/H and H/A according to the criteria established by Waterlow ${ }^{21}$. This method allowed the calculation of W/H and $\mathrm{H} / \mathrm{A}$ adequacy with respect to the $50 \%$ weight and height percentiles of the National Center for Health Statistics (NCHS) standards ${ }^{22}$. Laboratory tests 
Table 1. Composition of the nutritional supplement taken by patients during the study.

\begin{tabular}{|c|c|}
\hline Nutrients & Amount \\
\hline Vitamin A (UI) & 5000,0 \\
\hline Vitamin E (UI) & 30,0 \\
\hline Vitamin C (mg) & 60,0 \\
\hline Pantothenic acid (mg) & 10,0 \\
\hline Folic acid (mcg) & 400,0 \\
\hline Biotin (mcg) & 30,0 \\
\hline Calcium (mg) & 162,0 \\
\hline Vitamin $B_{12}(\mathrm{mcg})$ & 6,0 \\
\hline Vitamin $B_{6}(\mathrm{mg})$ & 2,0 \\
\hline Chlorine (mg) & 36,3 \\
\hline Copper (mg) & 2,0 \\
\hline Cholecalciferol (UI) & 400,0 \\
\hline Chrome (mcg) & 25,0 \\
\hline $\operatorname{Tin}(\mathrm{mcg})$ & 10,0 \\
\hline Iron (mg) & 18,0 \\
\hline Vitamin $\mathrm{K}_{1}(\mathrm{mcg})$ & 25,0 \\
\hline Phosphorus (mg) & 125,0 \\
\hline lodine (mcg) & 150,0 \\
\hline Magnesium (mg) & 100,0 \\
\hline Manganese (mg) & 2,5 \\
\hline Molybdenum (mcg) & 25,0 \\
\hline Thiamine (mg) & 1,5 \\
\hline Nicotinamide (mg) & 20,0 \\
\hline Nickel (mcg) & 5,0 \\
\hline Potassium (mg) & 40,0 \\
\hline Riboflavin (mg) & 1,7 \\
\hline Selenium (mcg) & 25,0 \\
\hline Silicon (mcg) & 10,0 \\
\hline Vanadium (mcg) & 10,0 \\
\hline Zinc (mg) & 15,0 \\
\hline
\end{tabular}

were also done to investigate possible nutritional deficiencies and diseases associated with the KD. The levels of albumin, total proteins, triglycerides, total cholesterol, Low Density Lipoproteincholesterol (LDL-C), High Density Lipoproteincholesterol (HDL-C), vitamin A, beta carotene, iron, calcium, phosphorus, potassium, sodium, zinc, magnesium, glycemia, urea, creatinine, Aspartate Transaminase (AST) and Alanine Transaminase (ALT) were measured and complete blood count done. Patients were examined at 1, 6, 12 and 24 months after KD introduction and 12 months after KD discontinuation.

The efficacy of the KD was assessed by means of seizure activity on the basis of seizure frequency recorded by the participants' parents.
RES U LTS

\section{Demographic data}

Thirteen (44.8\%) of the 29 patients were boys. The mean age at epilepsy onset was 6.5 months (ranging from 0 to 30 months), and the mean age at the beginning of the KD diet was 6.1, Standard Deviation (SD)=3.4 years (ranging from 1 to 15 years). Subjects were kept on the $K D$ for a mean of 11 ( $S D=11)$ months. Seizure types included generalized symptomatic (62\%), focal symptomatic (24.1\%), generalized cryptogenic (10.3\%), and focal cryptogenic (3.6\%) events. Fifty percent of the patients with generalized symptomatic epilepsy had LennoxGastaut syndrome (9/18 patients). MRI findings were: cortical developmental abnormalities (34.5\%), diffuse cortical atrophy $(34.5 \%)$, gliosis (13.7\%) and congenital infection (3.6\%). MRI was normal for four patients. All patients had developmental delays, and delay was severe in $75.9 \%$ and moderate in $24.1 \%$ of the children. Seizure frequency ranged from three to numerous seizures daily.

All patients were submitted to interictal electroencephalogram before the introduction of the $K D$, revealing abnormal baseline activity. Almost all of them had moderate disorganization (27/29). Multifocal interictal epileptiform discharges were observed in high, moderate, and rare incidences in 17, 10, and 2 patients, respectively. All patients with Lennox-Gastaut syndrome had a high incidence of spikes.

\section{Nutritional assessment and side effects}

During hospital stay and before KD initiation, $34.5 \%$ of the participants had normal weight and $65.5 \%$ were undernourished; $51.7 \%$ had acute and $10.3 \%$ had chronic undernutrition, and $3.5 \%$ had had undernutrition in the past.

Of the seven participants that stayed on the KD until the end of the study, $14.3 \%$ had 
normal weight before starting the diet. The remainder $85.7 \%$ were undernourished, all of which had acute undernutrition. At the end of the study, patients presented with improved nutritional status, especially in terms of weight, recovering proper $\mathrm{W} / \mathrm{H}$. The final results were as follows: $28.6 \%$ of the subjects had normal weight, $71.4 \%$ were undernourished, $42.8 \%$ had had undernutrition in the past, that is, were presently stunted, and only $28.6 \%$ presented chronic undernutrition (Figure 1).

Analysis of biochemical parameters evidenced a significant rise in serum cholesterol levels in the first month, followed by a reduction at six months, and maintenance of constant values thereafter, with no significant differences six months after KD was discontinued (Figure 2).

There was no significant difference in the mean triglyceride levels during the $K D$, but $6.9 \%$ (2/29) of the participants had hypertriglyceridemia but the levels went back to normal at the end of the diet. Blood glucose of only one patient (1/29) did not stay within the reference values.

There were no changes in serum albumin in the first 6 months of the study. Only one patient (1/29) experienced severe hypoalbuminemia at 11 months, so the treatment was discontinued. There were no significant differences in serum albumin concentrations or in total serum protein concentrations of the other subjects throughout the study period,

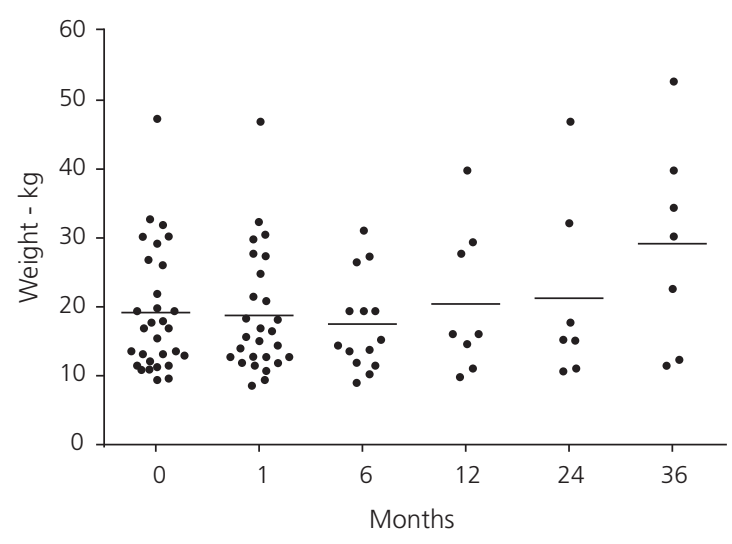

Figure 1. Weight over time in epileptic patients on a classic ketogenic diet.
A

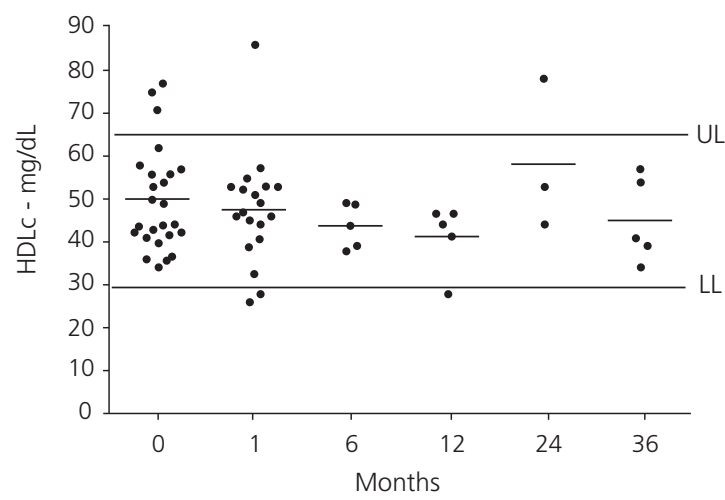

B

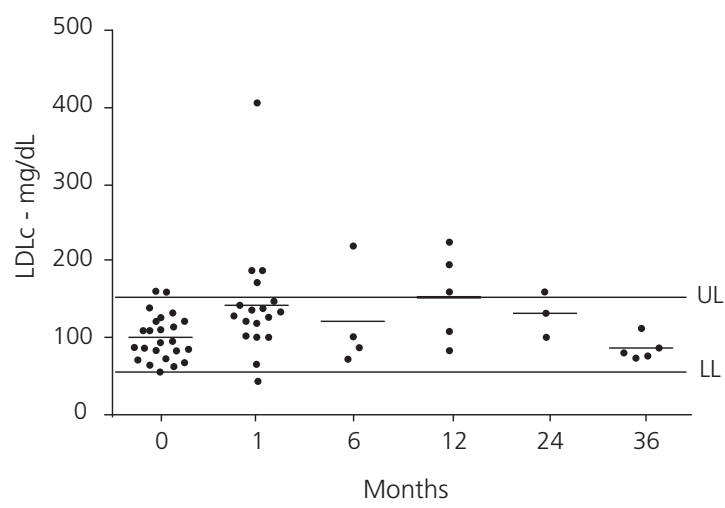

C

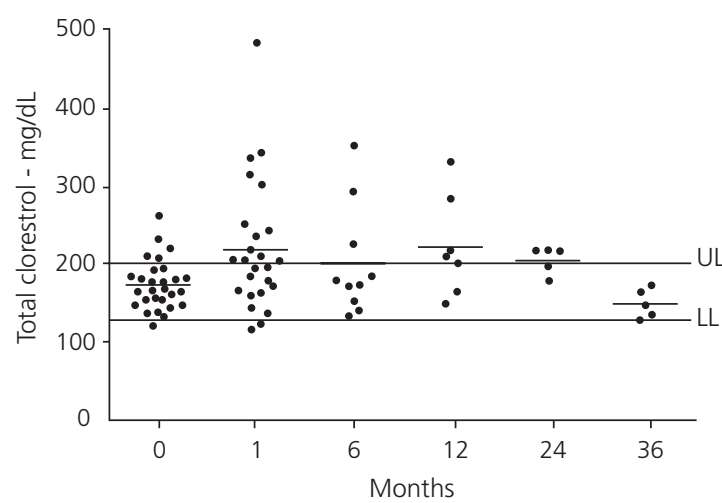

Figure 2. Serum HDL-C, LDL-C and total cholesterol levels over time in epileptic patients treated with the classic ketogenic diet.

Notas: HDL-c: High Density Lipoprotein-cholesterol; LDL-c: Low Density Lipoprotein-cholesterol; UL: Upper Limit; LL: Lower Limit. 
Six individuals (20.7\%) had high AST and ALT levels before the beginning of the KD. The liver function of these patients became normal after some time on the diet, and serum AST and ALT levels were within the normal ranges (Figure 3).
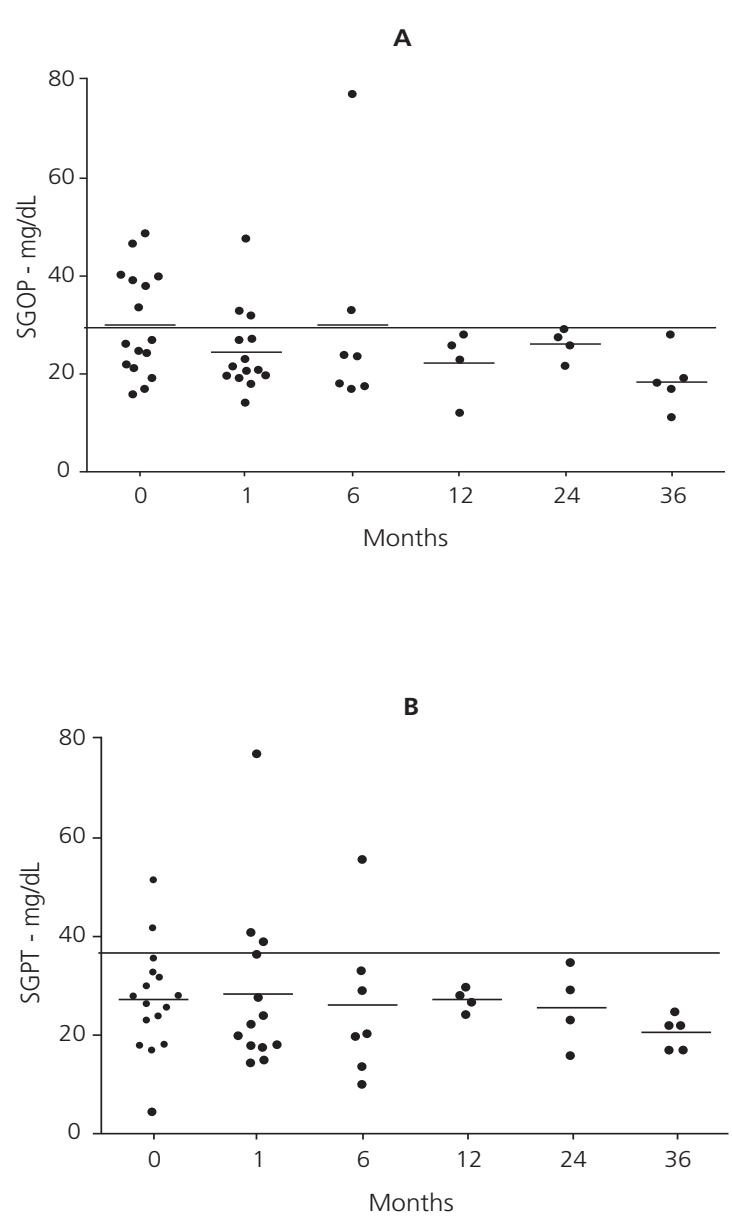

Figure 3. Serum Aspartate Transaminase and Alanine Transaminase levels over time in epileptic patients treated with the classic ketogenic diet.
The mean vitamin A, iron, calcium, phosphorus, potassium, sodium, zinc, magnesium, blood glucose, urea, and creatinine levels did not vary significantly throughout the study.

In the beginning of the KD, two patients discontinued treatment: one due to complications in the ventriculoperitoneal shunt (VP shunt) and another because of persistent vomiting. The commonest side effects after the initial stage of the diet were gastrointestinal symptoms (9/29): 6 patients had nausea and vomiting, 2 presented with constipation or diarrhea, and 1 experienced difficulty taking in fluids and accepting the diet. Two children had dehydration and severe metabolic acidosis, which led to hospitalization. They were intravenously hydrated with glucosefree solutions or lactate. In the long-term, the patients presented with other complications such as hypoalbuminemia, hypoproteinemia, waterelectrolyte imbalance, kidney stones, hypercholesterolemia, low fluid intake and refusal of the diet.

\section{Seizure frequency over time}

Only 7 of the initial 29 patients remained on the KD until the end of the study (Table 2). Within the first months of the diet, seven subjects dropped out of the study because of unresponsiveness to treatment; the seizure frequency of the remainder participants dropped so they stayed on the diet, and three children became seizure-free. At six months, five more children were excluded from the study for unresponsiveness; three were excluded because of adverse events; and 14 children had at least a

Table 2. Time course of the number of patients on the ketogenic diet in May, 2007.

\begin{tabular}{lccccc}
\hline Seizure frequency & 1 months $(n=29)$ & 6 months $(n=22)$ & 12 months $(n=14)$ & 24 months $(n=8)$ & After KD $(n=7)$ \\
\hline$>50 \%$ reduction of seizures & 19 & 7 & 4 & 2 & 2 \\
Seizure-free & 3 & 7 & 4 & 5 & 5 \\
Inefficient & 7 & 5 & 2 & - & - \\
Adverse events & - & 3 & 3 & 1 & - \\
Discontinued & - & - & 1 & - & - \\
\hline
\end{tabular}


$90 \%$ reduction in seizure frequency. Of the eight participants that were still on the diet at 12 months, four were completely seizure-free and four had a $90 \%$ reduction in seizure frequency. At 24 months, one patient presented with kidney stones and discontinued the treatment. At the end of 24 months, all patients discontinued the $\mathrm{KD}$ and were followed for another 12 months. During this period, five patients remained seizurefree and two patients had an increase in seizure frequency.

The dosages of the antiepileptic drug of patients with reduced seizure frequency and seizure-free were reduced. At the end of the study, two patients were medication-free and remained with the same seizure frequency or absence as the previous year, when KD was discontinued. Two participants continued taking the same dosage, and the dosages of three were reduced.

\section{DISCUSSION}

The retrospective assessment of 29 patients and the follow-up of seven children with refractory epilepsy placed on the classic KD resulted in good seizure control. Recovery of the nutritional status is essential for the proper growth and development of the patients, and the effect of the KD in this process is not clear. There are few studies on the risks posed by the KD, mainly with respect to its nutritional impact ${ }^{23}$. Studies have reported significant weight and height gains after 4 to 6 months of a KD24. Another similar study assessed the growth of children placed on a KD for one year and found that height and weight remained within the normal range; at the end of the study period, growth was similar to that of normal children. In contrast, Williams et al. ${ }^{25}$ reported that children on a KD followed for 1.2 years presented suboptimal growth, emphasizing the need for the nutritional follow-up of patients treated with this diet. Similar results have been observed by other authors. Tumas et al. ${ }^{26}$ demonstrated a decrease in mean weight-for-age and $\mathrm{H} / \mathrm{A}$ in 20 patients using a KD followed for
12 months, whereas Peterson et al. ${ }^{27}$ detected significant reduction of $\mathrm{H} / \mathrm{A}$ and W/A Z-scores and percentiles in children using a KD for 12 months.

In the present study, there was a high percentage of previously undernourished patients, but after the 24-month study period or longer, these patients reached a normal weight. This result confirms the findings of Liu et al. ${ }^{24}$ and is probably related to adequate daily energy intake. However, considering the long-term effect of the $K D$ on growth rates, the height of the present sample did not recover after a 24-month followup. Liu et al. ${ }^{24}$ observed height recovery after a short follow-up period, but other studies involving the use of KD and longer follow-ups did not corroborate their findings, suggesting that patients on long-term use of KD should be closely monitored $^{26,27}$.

Some studies have evidenced a slight rise in total cholesterol and triglyceride levels in children on the KD because of refractory epilepsy ${ }^{28}$. Hosain et al. ${ }^{29}$ demonstrated that total cholesterol and triglycerides significantly increased in $14.5 \%$ and $36.2 \%$ of the patients on a KD, respectively; however, cholesterol concentrations higher than $230 \mathrm{mg} / \mathrm{dL}$ and serum triglyceride levels higher than $190 \mathrm{mg} / \mathrm{dL}$ were considered high in their work. Liu et al. ${ }^{24}$ have compared the classic KD with the KD based on medium-chain triglycerides (MCT) and showed that patients following the classic KD had increased total cholesterol and LDL levels, whereas those that received MCT had significant reduction in total cholesterol and LDL, with increased $\mathrm{HDL}$.

Laboratory tests revealed similar results for serum albumin, blood glucose and liver enzymes when compared with baseline findings during KD use. These data agree with those published by other authors ${ }^{14,30}$.

The efficacy of the KD for the treatment of epilepsy is currently widely accepted. Kang et al. ${ }^{31}$ have described that after a 12 -month period on the classic KD, 23 to $44 \%$ of the patients had a $50 \%$ decrease in seizure activity, and $7 \%$ to $22 \%$ of these were completely seizure-free. 
In a study with patients following a KD, Hartman \& Vining ${ }^{32}$ investigated how age, sex, epileptic syndrome, and electrographic pattern affected KD efficacy, but these authors did not find anything significant. Hence, these authors suggested that KD should be considered an alternative treatment for any patient with drug-resistant epilepsy.

\section{CONCLUSION}

Despite the small size of our sample, our results corroborate the use of KD as an important and effective alternative for the treatment of patients with refractory epilepsy. However, a more detailed nutritional follow-up is essential to ensure appropriate nutrition to the growth and development of these patients.

\section{CONTRIBUTORS}

LD MARTINS was responsible for the experimental design, data collection and analysis, and writing of the manuscript. CF NICOLETTI was responsible for data collection and writing of the manuscript. CB NONINO was responsible for the experimental design, data analysis, provision of significant advice, consultation, and supervision of the study. JS MARCHINI, VC TERRA, AC SAKAMOTO, and PG CHIARELLO were responsible for data analysis, provision of significant advice, and consultation. All authors were responsible for the critical revision of the manuscript for important intellectual content.

\section{REFERENCES}

1. Kossoff EH, Zupec-Kania BA, Rho JM. Ketogenic diets: an update for child neurologists. J Child Neurol. 2009; 24(8):979-88.

2. Kessler SK, Neal EG, Camfield CS, Kossoff EH. Dietary therapies for epilepsy: future research. Epilep Behav. 2011; 22(1):17-22.

3. Kossoff EH, Zupec-Kania BA, Amark PE, et al. Optimal clinical management of children receiving the ketogenic diet: recommendations of the International Ketogenic Diet Study Group. Epilepsia. 2009; 50(2):304-17.
4. Bainbridge $\mathrm{J}$, Gidal BE, Ryan M. The ketogenic diet. Pharmacoterapy. 1999; 19(6):782-6.

5. Kelley SA, Kossoff EH. Doose syndrome (myoclonicastatic epilepsy): 40 years of progress. Dev Med Child Neurol. 2010; 52:988-93.

6. Schwartz RH, Eaton J, Bower BD. Ketogenic diets in the treatment of epilepsy: short-term clinical effects. Dev Med Child Neurol. 1989; 31(2):145-51.

7. The American Dietetic Association. Manual of clinical dietetics. Chicago: The American Dietetic Association; 1998. p.455-66.

8. Freeman JM, Vining EPG, Pillas DJ, Pyzik PL, Casey JC, Kelly LM. The efficacy of ketogenic diet: a prospective evolution of intervention in 150 children. Pediatrics. 1998; 102(6):1358-63.

9. Neal EG, Cross JH. Efficacy of dietary treatments for epilepsy. J Hum Nutr Diet. 2010; 23:113-9.

10. Huffman J, Kossoff HE. State of the ketogenic diet(s) in epilepsy. Epilepsia. 2007; 48:43-58.

11. Katyal NG, Koehler AN, McGhee B, Foley CM, Crumrine PK. Ketogenic diet in refractory epilepsy: the experience of children's Hospital of Pittsburgh. Clin Pediatr. 2000; 39(3):153-9.

12. Artigas J. Psychological manifestations of epilepsy in childhood. Rev Neurol. 1999; 28(Suppl 2): S135-41.

13. Volpe SL, Schall JI, Gallagher PR, Stallings VA, Bergqvist AGC. Nutrient intake of children with intractable epilepsy compared with healthy children. J Am Diet Assoc. 2007; 107(6):1014-18.

14. Richard D, Ferland J, Lalonde J, Samson P, Deshaies $Y$. Influence of topiramate in the regulation of energy balance. Nutrition. 2000; 16(10):961-6.

15. Thommessen M, Kase BF, Riis G, Heiberg A. The impact of feeding problems on growth and energy intake in children with cerebral palsy. Eur J Clin Nutr. 1991; 45(10):479-87.

16. Bertoli S, Cardinali P, Veggiotti P, Trentani C, Testolin $G$, Tagliabue A. Evaluation of nutritional status in children with refractory epilepsy. Nutr J. 2006; 5: 14-22.

17. Mainardi P, Albano C. Is the antiepileptic effect of the ketogenic diet due to ketones? Med Hypotheses. 2008; 70(3):536-9.

18. Wheless JW. Nonpharmacologic treatment of the catastrophic epilepsies of childhood. Epilepsia. 2004; 45(Suppl 5):S17-22.

19. Hauser W, Hesdorffer DC. The natural history of seizures. In: Wyllie E. The treatment of epilepsy: principles and practice. Baltimore: Williams \& Wilkins; 1996. p.173-8.

20. Commission on Classification and Terminology of the International League Against Epilepsy. Proposal 
for revised classification of epilepsies and epileptic syndromes. Epilepsia. 1989; 30(4):389-99.

21. Waterlow JC. Note on the assessment and classification of protein-energy malnutrition in children. Lancet. 1973; 14(2):87-9.

22. National Center for Health Statistics. NCHS Growth curves for children birth - 18 years. Washington (DC): Government Printing Office; 1977. Departament of Health Education and Welfare publication $n^{\circ}$ (PHS) 78-1650. Vital and Health Statistics; serie 11; n. 165.

23. Papandreou D, Pavlou E, Kalimeri E, Mavromichlis I. The ketogenic diet in children with epilepsy. Br J Nutr. 2006; 95(1):5-13.

24. Liu YMC, Williams S, Basualdo-Hommond C, Stephens D, Curtis R. A prospective study: growth and nutrition status of children treated with the ketogenic diet. J Am Diet Assoc. 2003; 103(6): 707-12.

25. Williams S, Basualdo-Hammond C, Curtis R. Growth retardation in children with epilepsy on the ketogenic diet: a retrospective chart review. J Am Diet Assoc. 2002; 102(3): 405-7.

26. Tumas R, Lopes Cardoso A, Marques-Dias MJ, Vieira MA. Ketogenic diet in epileptic children: clinical and laboratory assessment. Nutr Hosp. 2010; 25(2): 317-8.
27. Peterson SJ, Tangney CC, Pimentel-Zablah EM, Hjelmgren B, Booth G, Berry-Kravis E. Changes in growth and seizure reduction in children on the ketogenic diet as a treatment for intractable epilepsy. J Am Diet Assoc. 2005; 105(5):718-25.

28. Freeman JM, Kossof EH, Hartman AL. The ketogenic diet: one decade later. Pediatrics. 2007; 119: 535-43.

29. Hosain SA, Vega-Talbott ML, Solomon GE. Ketogenic diet in pediatric epilepsy patients with gastrostomy feeding. Pediatr Neurol. 2004; 32(2): 81-3.

30. Kim DW, Kang HC, Park JC, Kim HD. Benefits of the nonfasting ketogenic diet compared with the initial fasting ketogenic diet. Pediatrics. 2004; 114(6):1627-30.

31. Kang HC, Kim YJ, Kim DW, KimHD. Efficacy and Safety of the ketogenic diet for intratable epilepsy: korean multicentric experience. Epilepsia. 2005; 46(2):272-9.

32. Hartman AL, Vining EPG. Clinical aspects of the ketogenic diet. Epilepsia. 2007; 48(1):31-42.

Received on: 27/5/2011

Final version on: 4/6/2012 Approved on: 25/6/2012 
